\author{
Kurt Pregitzer - Wendy Loya - Mark Kubiske \\ Donald Zak
}

\title{
Soil respiration in northern forests exposed to elevated atmospheric carbon dioxide and ozone
}

Received: 21 June 2005/ Accepted: 25 January 2006

(C) Springer-Verlag 2006

\begin{abstract}
The aspen free-air $\mathrm{CO}_{2}$ and $\mathrm{O}_{3}$ enrichment (FACTS II-FACE) study in Rhinelander, Wisconsin, USA, is designed to understand the mechanisms by which young northern deciduous forest ecosystems respond to elevated atmospheric carbon dioxide $\left(\mathrm{CO}_{2}\right)$ and elevated tropospheric ozone $\left(\mathrm{O}_{3}\right)$ in a replicated, factorial, field experiment. Soil respiration is the second largest flux of carbon (C) in these ecosystems, and the objective of this study was to understand how soil respiration responded to the experimental treatments as these fast-growing stands of pure aspen and birch + aspen approached maximum leaf area. Rates of soil respiration were typically lowest in the elevated $\mathrm{O}_{3}$ treatment. Elevated $\mathrm{CO}_{2}$ significantly stimulated soil respiration $(8-26 \%)$ compared to the control treatment in both community types over all three growing seasons. In years 6-7 of the experiment, the greatest rates of soil respiration occurred in the interaction treatment $\left(\mathrm{CO}_{2}+\mathrm{O}_{3}\right)$, and rates of soil respiration were $15-25 \%$ greater in this treatment than in the elevated $\mathrm{CO}_{2}$ treatment, depending on year and community type. Two of the treatments, elevated $\mathrm{CO}_{2}$ and elevated $\mathrm{CO}_{2}+\mathrm{O}_{3}$, were fumigated with ${ }^{13} \mathrm{C}$-depleted $\mathrm{CO}_{2}$, and in these two treatments we used standard isotope mixing models to understand the proportions of new and old $\mathrm{C}$ in soil respiration. During the peak of the growing season, C
\end{abstract}

Communicated by Jim Ehleringer

K. Pregitzer $(\bowtie) \cdot$ W. Loya

Ecosystem Science Center, School of Forest Resources and Environmental Science, Michigan Technological University, 1400 Townsend Ave., Houghton, MI, 49931, USA

E-mail: kspregit@mtu.edu

Fax: + 1-906-4872915

M. Kubiske

USDA Forest Service North Central Research Station, Rhinelander, WI, 54501, USA

D. Zak

School of Natural Resoures and the Environment, and Department of Ecology and Evolutionary Biology, University of Michigan, Ann Arbor, MI, 48109-1115, USA fixed since the initiation of the experiment in 1998 (new C) accounted for $60-80 \%$ of total soil respiration. The isotope measurements independently confirmed that more new $\mathrm{C}$ was respired from the interaction treatment compared to the elevated $\mathrm{CO}_{2}$ treatment. A period of low soil moisture late in the 2003 growing season resulted in soil respiration with an isotopic signature $4-6 \%$ enriched in ${ }^{13} \mathrm{C}$ compared to sample dates when the percentage soil moisture was higher. In 2004, an extended period of low soil moisture during August and early September, punctuated by a significant rainfall event, resulted in soil respiration that was temporarily $4-6 \%$ more depleted in ${ }^{13} \mathrm{C}$. Up to $50 \%$ of the Earth's forests will see elevated concentrations of both $\mathrm{CO}_{2}$ and $\mathrm{O}_{3}$ in the coming decades and these interacting atmospheric trace gases stimulated soil respiration in this study.

Keywords Air pollution Carbon cycling Global change $\cdot$ Stable isotope $\cdot \delta^{13} \mathrm{C}$

\section{Introduction}

Human activity has increased the concentration of carbon dioxide $\left(\mathrm{CO}_{2}\right)$ and ozone $\left(\mathrm{O}_{3}\right)$ in the Earth's troposphere, and each of these trace gases has the potential to modify photosynthesis and plant growth across broad geographic regions, albeit in diametrically opposing ways. For example, higher-than-ambient concentrations of atmospheric $\mathrm{CO}_{2}$ tend to stimulate photosynthesis and plant growth (Curtis and Wang 1998; Ainsworth and Long 2005), whereas elevated $\mathrm{O}_{3}$ generally has the opposite effect (Krupa et al. 2000; Felzer et al. 2004). By the end of this century, nearly one-half of the Earth's forests will be growing in an atmosphere with elevated concentrations of both of these trace gases (Albritton et al. 2001; Fowler et al. 1998, 1999). Recent evidence indicates that higher rates of photosynthesis and plant growth under elevated $\mathrm{CO}_{2}$ can be nullified by $\mathrm{O}_{3}$ concentrations that already occur across many regions of the Earth (Karnosky et al. 2003, 2005). Moreover, the 
magnitude of this response can vary widely among plant species and among genotypes of particular plant species (Karnosky et al. 2003). Because photosynthesis initiates the flow of energy through terrestrial ecosystems, variation in plant growth response to $\mathrm{CO}_{2}$ and $\mathrm{O}_{3}$ could cascade in species-specific ways through higher trophic levels, which further control the flow of energy and nutrients in terrestrial ecosystems (e.g., microbial decomposers in soil). At the present time, we do not have the ability to predict the interactive effects of $\mathrm{CO}_{2}$ and $\mathrm{O}_{3}$ on a wide array of biological processes from the molecular to ecosystem level, including soil respiration - one of the two largest fluxes of carbon (C) in forest ecosystems.

The flux of $\mathrm{CO}_{2}$ from soil is a sensitive indicator of a physiological change in plant roots, soil microorganisms, or both. One might expect soil respiration to track plant growth, and this has been the case for a variety of single factor experiments, where soil respiration is routinely stimulated by exposure to elevated $\mathrm{CO}_{2}$ (reviewed by Zak et al. 2000; King et al. 2004).

On the other hand, experiments that expose plants to elevated levels of atmospheric $\mathrm{O}_{3}$ typically decrease availability of photosynthate for export to roots, and roots become a relatively weaker sink for plants exposed to elevated $\mathrm{O}_{3}$ (Manning et al. 1971; Gorissen and van Veen 1988; Rennenberg et al. 1996; Anderson 2003). In many cases, decreased $\mathrm{C}$ allocation to roots occurs rapidly after exposure to elevated $\mathrm{O}_{3}$. Therefore, terrestrial ecosystems exposed to elevated $\mathrm{O}_{3}$ often have lower levels of root non-structural carbohydrates and lower rates of root and soil respiration (Grulke et al. 2001; Coleman et al. 1996; Anderson 2003). Little is known about the interactive effects of elevated $\mathrm{CO}_{2}+\mathrm{O}_{3}$ on soil respiration, although a recent report suggests the combination of the two trace gases stimulates soil respiration (Kasurinen et al. 2004).

The FACTS II-FACE Experiment in Rhinelander, Wisconsin, USA, provides a unique opportunity to understand how young, fast-growing forests exposed to elevated $\mathrm{CO}_{2}$ and $\mathrm{O}_{3}$ influence soil respiration in a longterm, replicated, factorial, field experiment. Two of the treatments, elevated atmospheric $\mathrm{CO}_{2}$ and the interaction treatment (elevated $\mathrm{CO}_{2}+\mathrm{O}_{3}$ ), are fumigated with highly depleted ${ }^{13} \mathrm{CO}_{2}$. In these two treatments, it is possible to partition soil respiration into a pool of $\mathrm{C}$ that existed before the experiment began ("old C") and a pool of "new C" fixed by photosynthesis since the initiation of the experiment. Based on what we knew about the effects of elevated atmospheric $\mathrm{CO}_{2}$ and $\mathrm{O}_{3}$ on photosynthesis and tree growth, we hypothesized that soil respiration would track net primary productivity (NPP) and exhibit a rank order among the treatments as follows: elevated $\mathrm{CO}_{2}>$ control $\approx$ elevated $\mathrm{CO}_{2}+\mathrm{O}_{3}>$ elevated $\mathrm{O}_{3}$; we expected these patterns would remain consistent through time. We also hypothesized that proportionally more new $\mathrm{C}$ would be respired from the elevated $\mathrm{CO}_{2}$ treatment compared to the interaction treatment, because NPP would be greater at elevated $\mathrm{CO}_{2}$. Here, we report soil respiration for years $5-7$ of the experiment, as well as our analysis of the $\delta^{13} \mathrm{C}$ of soil respiration. In the two treatments where it is possible to partition the flux of $\mathrm{CO}_{2}-\mathrm{C}$ into new $\mathrm{C}$ and old $\mathrm{C}$, we describe the proportion of new $\mathrm{C}$ in soil respiration and how it varies through time.

\section{Materials and methods}

Research area and field experiment

The FACTS II-FACE experiment in Rhinelander, Wisconsin, USA $\left(49^{\circ} 40.5^{\prime} \mathrm{N}, 89^{\circ} 37.5^{\prime} \mathrm{E}, 490 \mathrm{~m}\right.$ elevation) exposes trees to four different atmospheric trace-gas treatments (elevated $\mathrm{CO}_{2}$, elevated $\mathrm{O}_{3}$, elevated $\mathrm{O}_{3}+\mathrm{CO}_{2}$, and (ambient) control). The four treatments are arranged in a randomized complete block design with three replicates of each treatment. FACE technology combines a trace gas monitoring system with a delivery system comprised of blowers and vertical pipes placed around the perimeter of the forest stand to elevate ambient concentrations of $\mathrm{O}_{3}$ and $\mathrm{CO}_{2}$ (Dickson et al. 2000). Ambient levels of $\mathrm{CO}_{2}$ and $\mathrm{O}_{3}$ averaged $356 \mathrm{ppm}$ and $36 \mathrm{ppb}$, respectively, since the experiment began in 1998 through 2004. Elevated $\mathrm{CO}_{2}$ and elevated $\mathrm{O}_{3}$ treatments averaged $534 \mathrm{ppm}$ and $50 \mathrm{ppb}$, respectively. Detailed $\mathrm{O}_{3}$ exposure profiles can be found in Karnosky et al. (2005). The experiment was initiated in the summer of 1997 with the planting of greenhouse propagated tree seedlings at $1 \times 1 \mathrm{~m}$ spacing, in the following combinations within three sections of each $30 \mathrm{~m}$ ring: (1) aspen (Populus tremuloides Michx.); (2) birch (Betula papyrifera Marsh.) and aspen; and (3) maple (Acer saccharum Marsh.) and aspen. Fumigation began in May 1998. Elevated $\mathrm{CO}_{2}$ and $\mathrm{O}_{3}$ fumigation ran from 28 May-12 October 2002, 20 May-11 October 2003, and 21 May-17 October 2004. These dates correspond with the growing seasons during 2002, 2003 and 2004. Because of funding limitations, in this study we focused only on soil respiration in the aspen and birch + aspen community types. Soils at the site are mixed, frigid, coarse loamy Alfic Haplorthods. The texture of the soil is sandy loam, underlain by a clay loam Bt horizon, and then grading back into a sandy loam. At the end of the 2004 growing season, the canopies were closed in the dense stands of aspen and birch + aspen trees, and leaf area index (LAI) ranged from 2.5 to 4.0 , depending on treatment (Karnosky et al. 2005). These LAIs are typical of early successional natural stands of aspen and birch in the Lake States. Trees ranged in height from 5.3 to $8.1 \mathrm{~m}$ depending on treatment, and natural mortality (selfthinning) of individual trees had begun in these young, rapidly growing, dense stands.

Soil respiration and $\delta^{13} \mathrm{C}-\mathrm{CO}_{2}$ measurements

Soil respiration measurements were taken at ten locations within the aspen and birch + aspen community types of each experimental ring approximately every 
2 weeks throughout the growing season. Soil respiration collars, constructed of PVC pipe $10 \mathrm{~cm}$ in diameter and $6 \mathrm{~cm}$ in length, were randomly distributed throughout the central $10-\mathrm{m}$ core of each subsection. Collars were redistributed at the beginning of each growing season to reduce any bias associated with placement or effects of the collars on the soil or root growth, but remained in place throughout the growing season to minimize disturbance-induced effects in respiration measurements. Forest floor detritus was included in soil respiration measurements. All seedlings that germinated in the collars were immediately weeded from the collars throughout the growing season. Collars were inserted approximately $2.5 \mathrm{~cm}$ into the soil, and were designed to provide a gastight seal with a SRS-2 soil respiration chamber connected to an EGM-3 soil respiration monitor (PP Systems, Haverhill, Mass., USA). The EGM-3 soil respiration monitors were calibrated daily with a certified $\mathrm{CO}_{2}$ standard gas with concentrations adjusted for changes in atmospheric pressure. The PP Systems chamber may result in higher measured rates of soil respiration than measurements made with a LI-COR 6400-9 (LI-COR, Lincoln, Neb., USA; Janssens et al. 2000). Our own cross calibration between these two instruments made at the FACE experiment during 2004 follow this pattern, with the PP Systems rates 1.35 times higher than LI-COR rates (A.J. Burton et al., unpublished). We recognize these differences, but they should not influence the interpretation of our treatment responses.

To investigate the contribution of new $\mathrm{C}$ to total soil respiration in the elevated $\mathrm{CO}_{2}$ and elevated $\mathrm{O}_{3}+\mathrm{CO}_{2}$ treatments, we used the $\delta^{13} \mathrm{C}$ signature derived from the fossil-fuel fumigation gas as a tracer. The highly depleted $\mathrm{CO}_{2}$ is mixed with ambient air in the delivery system resulting in $\mathrm{CO}_{2}$ with distinctly different isotopic signatures (approximately $-22 \%$ in the elevated $\mathrm{CO}_{2}$ and elevated $\mathrm{CO}_{2}+\mathrm{O}_{3}$ treatments compared to $-8 \%$ o for the control and elevated $\mathrm{O}_{3}$ treatments). Subsequent fractionation by the plants produced leaf and root tissues that are significantly depleted in ${ }^{13} \mathrm{C}$ compared to leaves and roots produced under ambient $\mathrm{CO}_{2}$ and $\mathrm{O}_{3}$, making these new $\mathrm{C}$ inputs distinguishable from pretreatment soil $\mathrm{C}$.

The $\delta^{13} \mathrm{C}$ of soil respiration was measured at one (2002) or five (2003-2004) locations within each community type at bi-weekly to monthly intervals. To construct the chambers used to collect $\mathrm{CO}_{2}$ for $\delta^{13} \mathrm{C}$ analyses, the bottoms were cut off of 1-1 polypropylene wide-mouth bottles. Each wide-mouth bottle was then inserted to approximately $4 \mathrm{~cm}$ into the soil, which left a cylindrical collection chamber which was approximately $9 \mathrm{~cm}$ tall and $9 \mathrm{~cm}$ wide. A hole was drilled into the lid of each bottle and fitted snugly with red butyl rubber septa to allow for gas sampling. Bottles were left open until dates of sample collection, at which time the lids were screwed onto the bottle and bottles were left closed to allow $\mathrm{CO}_{2}$ to accumulate. To insure adequate concentration of $\mathrm{CO}_{2}$ for $\delta^{13} \mathrm{C}$ analyses, bottles were closed for $4 \mathrm{~h}$. A test early in the 2002 growing season to determine the effect of the amount of time chambers were closed on the $\delta^{13} \mathrm{C}$ of the $\mathrm{CO}_{2}$ revealed that the $\delta^{13} \mathrm{C}$ was stable at the time of sampling. Davidson (1995) reports that contamination of soil $\mathrm{CO}_{2}$ gas samples by atmospheric $\mathrm{CO}_{2}$ and the effects of fractionation can be minimized by increasing the elapsed time before sampling gas in closed chambers inserted into the soil. Collection of $\mathrm{CO}_{2}$ for $\delta^{13} \mathrm{C}$ analysis involved first removing an aliquot of $\mathrm{He}$ from a He-flushed and filled 10-ml Exetainer vial (Labco, UK) using a 20-ml plastic syringe fitted with a needle. We then collected the same volume of $\mathrm{CO}_{2}$ from the chambers by inserting the needle-nosed syringe through the septa, pulling an aliquot of gas, and injecting it into the Exetainer vial. In 2002, we collected $7 \mathrm{ml}$ of $\mathrm{CO}_{2}$ from each chamber. In 2003-2004, we collected $2 \mathrm{ml}$ of $\mathrm{CO}_{2}$ from each of the five chambers within a community type into a single gas tight syringe, and then injected $5 \mathrm{ml}$ (of the $10 \mathrm{ml}$ collected) of this composite gas sample into a single Exetainer vial. The vials were transported to the laboratory, and within $48 \mathrm{~h}$ the $\delta^{13} \mathrm{C}$ of the $\mathrm{CO}_{2}$ was measured on a FIN-MAT Gas Bench II connected to a Finnigan MAT Delta $^{\text {PLUS }}$, continuous flow-stable isotope ratio mass spectrometer (IRMS).

In September 2004, we compared the results from the method described above for estimating $\delta^{13} \mathrm{CO}_{2}$ with estimates from a Keeling plot approach (Pataki et al. 2003). On 19 September 2004, we collected soil respiration samples from the chambers in the elevated $\mathrm{CO}_{2}$ and elevated $\mathrm{CO}_{2}+\mathrm{O}_{3}$ treatments at 5-min intervals for the first $30 \mathrm{~min}$, followed by samples at 120, 180 and $240 \mathrm{~min}$. Samples for $\mathrm{CO}_{2}$ concentrations were collected by drawing $20 \mathrm{ml}$ of gas from the chamber via the septa, then flushing a crimp-capped 4-ml vial with $16 \mathrm{ml}$ of gas before injecting $4 \mathrm{ml}$ of sample into the vial. For $\delta^{13} \mathrm{CO}_{2}$, we collected $4 \mathrm{ml}$ of gas from each chamber and injected it into an Exetainer vial. Samples were transported to the laboratory where $\mathrm{CO}_{2}$ concentrations were measured on an Agilent 6890 Gas Chromatograph using a thermal conductivity detector (TCD) and $\delta^{13} \mathrm{CO}_{2}$ was measured according to methods described above.

\section{Plant $\delta^{13} \mathrm{C}$}

To estimate the contribution of newer plant $\mathrm{C}$ to soil respiration, we collected green leaf samples from the canopy in August 2003 and July 2004, and live roots from soil cores in August 1999, June 2003, and July 2004 , for $\mathrm{C}$ isotope analyses. We also measured $\delta^{13} \mathrm{C}$ values for leaf litter collected in the fall. The $\delta^{13} \mathrm{C}$ for leaves and leaf litter in the birch + aspen community type represent equally weighted means of individual species means. Fine roots were not separated by species, and the values in the birch + aspen community type represent a composite of both birch + aspen roots. Fresh plant tissues were frozen until they were oven dried at $65^{\circ} \mathrm{C}$. The dried samples were finely ground and 
weighed for analysis. The carbon isotope composition was determined using an Costech 4010 elemental analyzer connected by a Conflo III interface to a Finnigan MAT Delta ${ }^{\text {PLUS }}$, Continuous Flow-IRMS. Samples were measured against a $\mathrm{CO}_{2}$ reference gas calibrated with IAEA reference materials (International Atomic Energy Agency, Vienna, Austria). The standard deviation of repeated measurements of a laboratory standard was $0.10 \%$ for $\delta^{13} \mathrm{C}$.

\section{Soil temperature}

Soil temperature was measured at $5 \mathrm{~cm}$ depth adjacent to each soil respiration collar. Soil temperature and respiration measurements were always taken concurrently. Measurements were obtained using a stainless steel temperature probe (Taylor Scientific, St. Louis, Mo., USA).

\section{Soil water}

To better interpret intra-seasonal variation in soil respiration and $\delta^{13} \mathrm{CO}_{2}$, we report changes in the percentage of soil water at $10 \mathrm{~cm}$ depth from measurements that were taken at one location within each community type during the 2002-2004 growing seasons. Soil water was measured every 2 weeks at the same time the soil respiration and $\delta^{13} \mathrm{CO}_{2}$ measurements were taken. Measurements were obtained using a Trase Time Domain Reflectometry (TDR) System connected to a $20-\mathrm{cm}$ waveguide (Soilmoisture Equipment, Santa Barbra, Calif., USA) inserted into the soil at a $30^{\circ}$ angle.

\section{Data and statistical analysis}

The contribution of $\mathrm{C}$ derived from the fumigation gas was calculated using the equation percentage $(\%)$ new $\mathrm{C}=(\delta \mathrm{t}-\delta \mathrm{o}) /(\delta \mathrm{i}-\delta \mathrm{o}) \times 100$; where $\delta \mathrm{t}$ refers to the isotopic composition $\left(\delta^{13} \mathrm{C}\right)$ of soil respiration from the fumigated (elevated $\mathrm{CO}_{2}$ or elevated $\mathrm{O}_{3}+\mathrm{CO}_{2}$ ) treatments; $\delta$ o is the $\delta^{13} \mathrm{C}$ of soil respiration from the control treatment, and $\delta \mathrm{i}$ is the $\delta^{13} \mathrm{C}$ of the plant leaves and roots collected from the fumigated treatments (Loya et al. 2003). We calculated the mean and standard error of this percentage new $\mathrm{C}$ based on averaged component values as well as $95 \%$ confidence intervals based on variability within each component (Phillips and Gregg 2001). For 2002, $\delta$ i was estimated from the average $\delta^{13} \mathrm{C}$ value of leaves collected in 2001 for each species subsection by treatment and block and $\delta^{13} \mathrm{C}$ of fine roots collected in 1999. For 2003 and 2004, we used the average $\delta^{13} \mathrm{C}$ value of leaves and roots collected in 2003 and 2004, respectively, for each species subsection by treatment and block. For all years, leaf and root values were weighted equally in determining $\delta \mathrm{i}$. We recognize that plant respiratory $\mathrm{CO}_{2}$ is ${ }^{13} \mathrm{C}$-enriched relative to tissue $\delta^{13} \mathrm{C}$ (Xu et al. 2004), and that the choice of mixing-model end members will influence the partitioning of soil respiration into component fluxes. However, we use the mixing models simply to understand relative changes in the flux of new and old $\mathrm{C}$ over the course of this study. We also discuss the pitfalls of our methods and assumptions.

Differences among $\delta^{13} \mathrm{C}$ values, \% new $\mathrm{C}$ and soil respiration rates were analyzed by year using repeated measures analysis for a split-plot randomized complete block design using PROC MIXED for SAS 8.02 (Cary, N.C.) as detailed in King et al. (2001). Analyses were run separately by year because the sampling intervals and number of observations varied from year to year. Significance was determined at $P<0.05$.

\section{Results}

\section{Soil respiration}

Across all 3 years and both community types, rates of soil respiration exhibited significant temporal variation across each growing season $(P<0.05)$, with the highest rates of respiration occurring when the soils were warm in July, August and early September (Figs. 1, 2). The lowest rates of soil respiration always occurred during spring and fall when soil temperatures were relatively low and when the canopy had yet to develop or trees were entering dormancy (Figs. 1, 2).

In 2002, rates of soil respiration were significantly greater in the aspen compared to the birch + aspen community type (Fig. $2 \mathrm{a}$ vs $\mathrm{d} ; P=0.04$ ). In the aspen community type during the peak growing season (16 June-7 September), respiration rates were highest in the elevated $\mathrm{CO}_{2}$ treatment, and lower in the control, elevated $\mathrm{O}_{3}$, and $\mathrm{CO}_{2}+\mathrm{O}_{3}$ treatments (Fig. 2a). In the birch + aspen community type, rates of soil respiration were significantly higher in the elevated $\mathrm{CO}_{2}$ treatment, followed by the $\mathrm{CO}_{2}+\mathrm{O}_{3}$ treatment, while rates were similar in the elevated $\mathrm{O}_{3}$ and control treatments (Fig. 2d).

In 2003, across all treatments, there were no significant differences in rates of respiration among community types. However, we observed a shift to significantly greater rates of soil respiration in the elevated $\mathrm{CO}_{2}+\mathrm{O}_{3}$ treatment in both community types (Fig. 2b, e). In the aspen community type, rates of soil respiration in the elevated $\mathrm{CO}_{2}+\mathrm{O}_{3}$ treatment were approximately $20 \%$ greater than those under elevated $\mathrm{CO}_{2}$ during the peak of the growing season (23 June-18 September; Fig. 2b). Rates of soil respiration in the control treatment were greater than in the elevated $\mathrm{O}_{3}$ treatment. In the birch + aspen community type (Fig. 2e), rates were about $25 \%$ greater in the elevated $\mathrm{CO}_{2}+\mathrm{O}_{3}$ treatment when compared to the elevated $\mathrm{CO}_{2}$ treatment. Exposure to elevated $\mathrm{CO}_{2}$ alone resulted in rates of soil respiration significantly greater than those in the control treatment, while rates of soil respiration were lower in the elevated $\mathrm{O}_{3}$ treatment (Fig. 2e). 
Fig. 1 Soil temperature $(5 \mathrm{~cm}$ depth) for aspen and birch + aspen community types during the 2002-2004 growing seasons. Values are means with $1 \mathrm{SE}(n=3)$. Within each year and community type, $P$ values indicate significant treatment effects
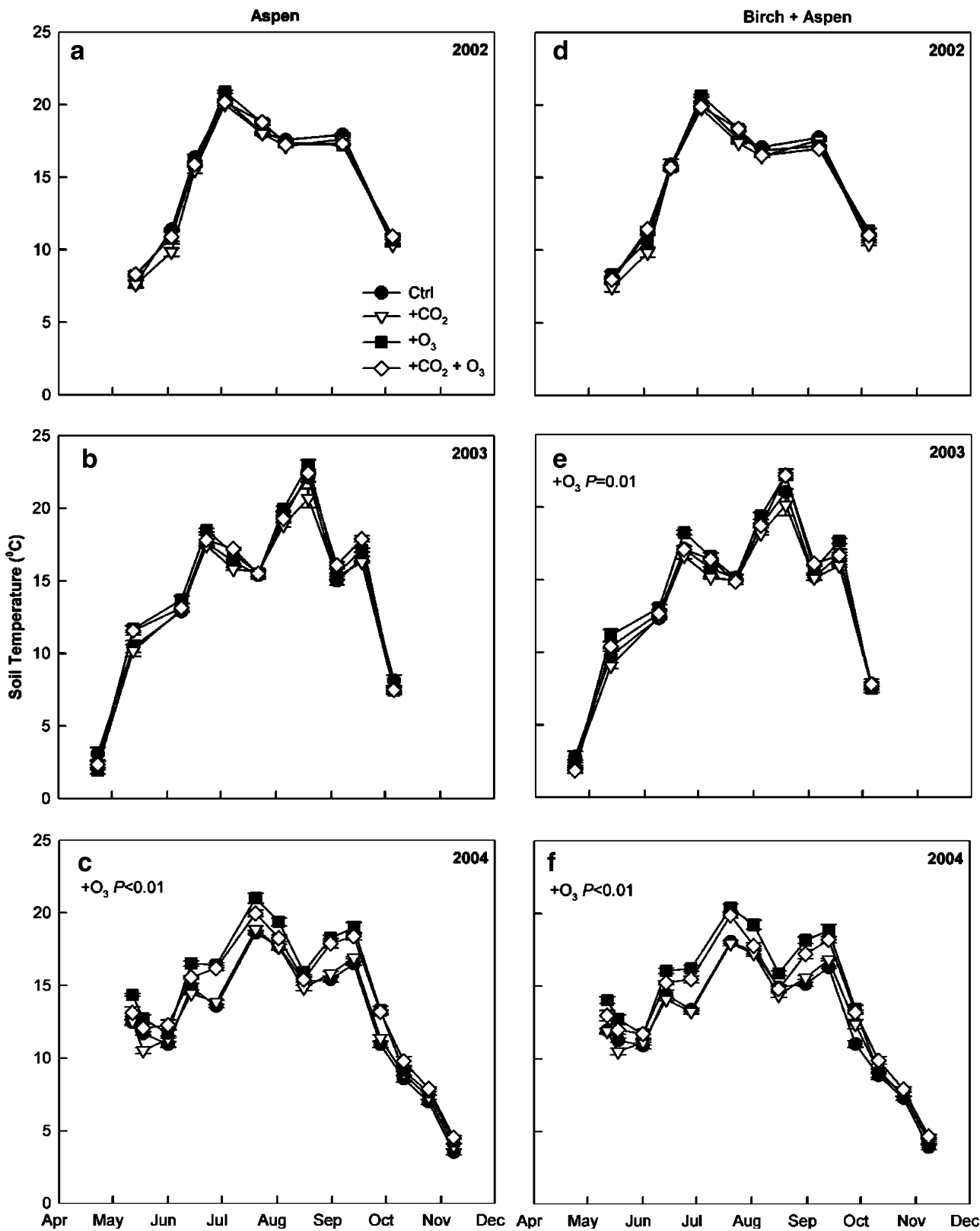

In 2004, across all treatments, rates of soil respiration were again significantly greater in the aspen community type compared to the birch + aspen community type (Fig. 2c vs f; $P=0.01$ ). Treatment effects on soil respiration observed in 2004 (Fig. 2c, f) were similar to those observed in 2003 (Fig. 2b, e). Significantly higher rates of soil respiration occurred in the elevated $\mathrm{CO}_{2}+\mathrm{O}_{3}$ treatment in both community types (Fig. 2c, f). Under elevated $\mathrm{CO}_{2}$, rates were similar between the community types and roughly $15 \%$ lower than the values observed in the elevated $\mathrm{CO}_{2}+\mathrm{O}_{3}$ treatment. However, rates of soil respiration at elevated $\mathrm{CO}_{2}$ were still significantly greater than rates in the control treatment across both community types (Fig. 2c, f). The lowest rates of soil respiration were again observed under elevated $\mathrm{O}_{3}$ across both community types, but treatment differences were not statistically significant. $\delta^{13} \mathrm{C}$ of soil respiration

Variation in the isotopic signature of plant modules is summarized in Table 1. Unlike some elevated $\mathrm{CO}_{2}$ experiments, fumigation was initiated when the trees were still small seedlings $(\sim 0.2 \mathrm{~m}$ tall $)$ and the fumigation gas has been highly depleted throughout plant ontogeny. Therefore, the $\delta^{13} \mathrm{C}$ of plant tissues and treatment differences among tissues have been relatively stable through the course of this experiment (Table 1). Fresh leaf litter was more depleted in ${ }^{13} \mathrm{C}$ than green leaves (Table 1), presumably because the relative concentration of lignin increases and non-structural carbohydrates decreases as the leaves senesce. Lignin is known to be at least $4 \%$ more depleted in ${ }^{13} \mathrm{C}$ than cellulose and non-structural carbohydrates (Ehleringer et al. 2000), and its relative concentration increases as non-structural 
Fig. 2 Soil respiration fluxes for aspen and birch + aspen community types during the 2002-2004 growing seasons. Values are means with $1 \mathrm{SE}$ $(n=3)$. Within each year and community type, $P$ values indicate significant treatment effects
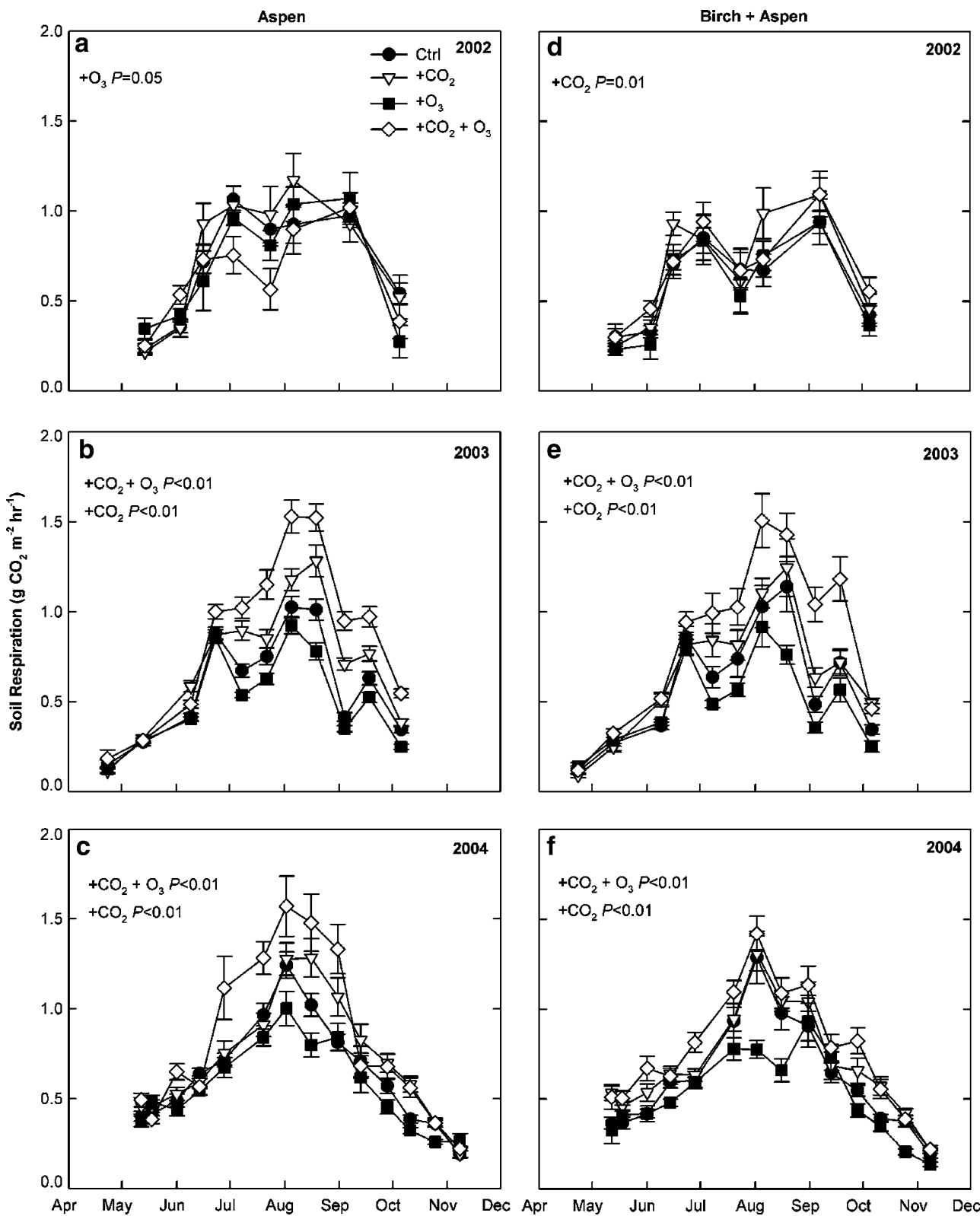

carbohydrates are retranslocated from leaves before leaf senescence.

The $\delta^{13} \mathrm{C}$ of soil respiration in the elevated $\mathrm{CO}_{2}$ and elevated $\mathrm{CO}_{2}+\mathrm{O}_{3}$ treatments reflected the isotopic signature of the fumigation gas used to increase atmospheric $\mathrm{CO}_{2}$ coupled with subsequent discrimination by the trees (Table 1, Fig. 3). In 2002, the $\delta^{13} \mathrm{C}$ of soil respiration in the control treatment was significantly more depleted in ${ }^{13} \mathrm{C}$ when contrasted with the $\delta^{13} \mathrm{C}$ of soil respiration in the $\mathrm{O}_{3}$ treatment (Fig. 3). In both the aspen and birch + aspen community types, the 2002 $\delta^{13} \mathrm{C}$ of soil respiration in the elevated $\mathrm{CO}_{2}$ treatment was significantly more depleted in ${ }^{13} \mathrm{C}$ than $\mathrm{CO}_{2}$ respired from the interaction treatment $\left(+\mathrm{CO}_{2}+\mathrm{O}_{3}\right.$, Fig. 3). In 2003 , there were no significant differences in the $\delta^{13} \mathrm{C}$ of soil respiration for any of the relevant contrasts (control vs $+\mathrm{O}_{3} ; \quad+\mathrm{CO}_{2}$ vs $+\mathrm{CO}_{2}+\mathrm{O}_{3} ;$ Fig. 3). In
2004, soil respiration in the birch + aspen control plots was once again (as in 2002), significantly more depleted in ${ }^{13} \mathrm{C}$ compared with the $\delta^{13} \mathrm{C}$ of soil respiration in the elevated $\mathrm{O}_{3}$ treatment (Fig. 3). Interestingly, in both the aspen and birch + aspen community types, the 2004 $\delta^{13} \mathrm{C}$ of soil respiration was more depleted in ${ }^{13} \mathrm{C}$ in the interaction treatment $\left(+\mathrm{CO}_{2}+\mathrm{O}_{3}\right)$ than in the elevated $\mathrm{CO}_{2}$ treatment, and the differences were statistically significant in the birch + aspen community type (Fig. 3).

Overall, the $\delta^{13} \mathrm{C}$ of soil respiration was lower in the birch + aspen community type, with significant differences between the aspen versus birch + aspen community types in all 3 years $(P<0.05)$. Growing season (June-September) average $\delta^{13} \mathrm{C}$ was approximately $-34 \%$ in the aspen community type (Fig. 3a-c) and $-36 \%$ in the birch + aspen community type (Fig. $3 d-f$ ). 
Table $1 \delta^{13} \mathrm{C}$ values of leaves, leaf litter, and fine roots in elevated $\mathrm{CO}_{2}$, elevated $\mathrm{O}_{3}$, elevated $\mathrm{CO}_{2}+\mathrm{O}_{3}$, and control plots

\begin{tabular}{|c|c|c|c|c|c|c|c|c|c|}
\hline Tissue & Year & \multicolumn{2}{|l|}{$+\mathrm{CO}_{2}$} & \multicolumn{2}{|c|}{$+\mathrm{CO}_{2}+\mathrm{O}_{3}$} & \multicolumn{2}{|l|}{ Control } & \multicolumn{2}{|l|}{$+\mathrm{O}_{3}$} \\
\hline \multirow{2}{*}{ Fine roots } & 2003 & $-40.4(1.1)$ & $-42.9(1.4)$ & $-38.9(0.9)$ & $-42.8(0.8)$ & $-27.6(0.1)$ & $-28.2(0.1)$ & $-27.0(0.1)$ & $-27.5(0.3)$ \\
\hline & 2004 & $-41.2(0.3)$ & $-42.3(0.9)$ & $-40.6(0.4)$ & $-43.0(0.4)$ & $-27.6(0.2)$ & $-27.9(0.1)$ & $-27.3(0.1)$ & $-28.1(0.4)$ \\
\hline \multirow[t]{2}{*}{ Leaves } & 2001 & $-42.4(0.3)$ & $-42.5(0.3)$ & $-42.4(0.4)$ & $-42.8(0.3)$ & $-28.3(0.3)$ & $-28.3(0.2)$ & $-28.0(0.4)$ & $-28.5(0.2)$ \\
\hline & 2003 & $-40.2(1.4)$ & $-39.2(1.2)$ & $-37.9(1.4)$ & $-42.3(2.3)$ & $-27.4(1.0)$ & $-26.7(0.5)$ & $-26.0(0.8)$ & $-26.0(0.8)$ \\
\hline Leaf litter & 2003 & $-43.6(0.4)$ & $-43.2(0.7)$ & $-43.3(1.2)$ & $-44.9(0.7)$ & $-28.6(0.1)$ & $-29.0(0.1)$ & $-28.5(0.0)$ & $-28.8(0.1)$ \\
\hline
\end{tabular}

Values are mean $\delta^{13} \mathrm{C}(\%)$ with standard error in parentheses

In control treatments, the bi-weekly $\delta^{13} \mathrm{C}$ means averaged roughly $-22 \%$ in the aspen community type (Fig. 3a-c) and $-23 \%$ in the birch + aspen community type (Fig. 3d-f). Apparently, birch trees normally discriminate against ${ }^{13} \mathrm{C}$ slightly more than aspen trees, regardless of the concentration or isotopic signature of atmospheric $\mathrm{CO}_{2}$.

We compared the results from our ${ }^{13} \mathrm{CO}_{2}$ monitoring method with those obtained using a Keeling plot approach. With Keeling plots, the $\delta^{13} \mathrm{C}$ of soil respiration would be the $y$ intercept for a linear regression fit to $\delta^{13} \mathrm{CO}_{2}$ values of samples collected over time plotted against the inverse of the $\mathrm{CO}_{2}$ concentration of each sample. Using this method, on 19 September 2004 we found the $\delta^{13} \mathrm{C}$ of soil respiration to be $-33.7 \%$ and $-34.0 \%$ in the elevated $\mathrm{CO}_{2}$ and elevated $\mathrm{CO}_{2}+\mathrm{O}_{3}$ treatments, respectively (Fig. 4a). In contrast, the mean $\delta^{13} \mathrm{C}$ of $\mathrm{CO}_{2}$ for samples collected $4 \mathrm{~h}$ after sealing the chambers was $-31.9 \%$ and $-32.7 \%$ for these same treatments (Fig. 4b). Figure $4 \mathrm{~b}$ demonstrates that the $\delta^{13} \mathrm{C}$ of soil $\mathrm{CO}_{2}$ in the bottles stabilizes after $4 \mathrm{~h}$, confirming our original tests conducted early in the 2002 growing season. The difference of -1.8 to $-1.3 \%$ between the Keeling plot and $4 \mathrm{~h}$ average can be attributed in part to some contamination of the samples by ambient air present in the bottles when they are closed. We assumed the initial $\mathrm{CO}_{2}$ concentration in the chambers was approximately $600 \mathrm{ppm}$ because the canopy values averaged $534 \mathrm{ppm}$ (see above). The $\mathrm{CO}_{2}$ concentrations 5 min after screwing on the lid were approximately $1,000 \mathrm{ppm}$ (Fig. 4b). The isotopic signature of the ambient air at ground level is difficult to discern, but was likely to be less depleted than $-26 \%$, the $\delta^{13} \mathrm{C}$ of soil respiration measured at 5 min (Fig. 4b). Periodic samples of the atmosphere $1.5 \mathrm{~m}$ above the ground have averaged approximately $-22 \%$ (data not shown). Concentrations of $\mathrm{CO}_{2}$ are approximately $6,000 \mathrm{ppm}$ at 2-4 h (Fig. 4b), so contamination of soil respiration collected in the chambers at $4 \mathrm{~h}$ by atmospheric $\mathrm{CO}_{2}$ trapped in the bottles when the lids were closed averaged $8 \%$ (range $5-21 \%$ ). If we correct the $\delta^{13} \mathrm{C} 4 \mathrm{~h}$ value for the $8 \%$ of atmospheric $\mathrm{CO}_{2}$ trapped in the chambers when the lids were closed, this results in a $0.5 \%$ decrease in the $\delta^{13} \mathrm{C}$ of $\mathrm{CO}_{2}$, or corrected estimates of $-33 \%$ and
$-33.9 \%$ for the $4 \mathrm{~h}$ values in the elevated $\mathrm{CO}_{2}$ and elevated $\mathrm{CO}_{2}+\mathrm{O}_{3}$ treatments, respectively. Thus, there was only a small discrepancy $(0.1-0.7 \%$ o between our method and estimates from the Keeling plot method on the day we compared the two methods. For clarity, we simply report the uncorrected $2-4 \mathrm{~h} \quad \delta^{13} \mathrm{C}$ of $\mathrm{CO}_{2}$ throughout the manuscript (Fig. 3) and use these uncorrected values in our calculations of the percentage of new $\mathrm{C}$ in soil respiration (Fig. 5). We discuss the ramifications of using uncorrected $4 \mathrm{~h}$ values below.

\section{New $\mathrm{C}$ in soil respiration}

During the course of the entire 2002 growing season (June-September) we found that, in the aspen community type, approximately $70-75 \%$ of soil respiration in the elevated $\mathrm{CO}_{2}$ treatment was derived from new $\mathrm{C}(\mathrm{C}$ entering the soil since fumigation began in 1998; Fig. 5a). The percentage of new $\mathrm{C}$ in the elevated $\mathrm{CO}_{2}$ treatment was significantly greater than the percentage of new $\mathrm{C}$ in the elevated $\mathrm{CO}_{2}+\mathrm{O}_{3}$ treatment. Similar results were found for the birch + aspen community type, with nearly identical growing season averages (Fig. 5d).

In 2003, there were significantly greater losses of new $\mathrm{C}$ from the elevated $\mathrm{CO}_{2}+\mathrm{O}_{3}$ treatment compared to the elevated $\mathrm{CO}_{2}$ treatment in the aspen community type (Fig. 5b). From June through September 2003, the amount of new $\mathrm{C}$ in soil respiration ranged from 72 to $78 \%$ in the elevated $\mathrm{CO}_{2}+\mathrm{O}_{3}$ treatment, compared to $65-68 \%$ in the elevated $\mathrm{CO}_{2}$ treatment. This pattern of more new $\mathrm{C}$ respiring in the interaction treatment was not observed in the birch + aspen treatment in 2003. In this community type, more new $\mathrm{C}$ was respired from the elevated $\mathrm{CO}_{2}$ treatment when compared with the interaction treatment early in the growing season (May-midJune), whereas similar amounts were respired later in the growing season (July-September; Fig. 5e).

During the relatively cool summer of 2004, there was no significant treatment effect on the amount of new $\mathrm{C}$ in soil respiration in the aspen community type, where new $\mathrm{C}$ in soil respiration averaged about $60 \%$ during the growing season (Fig. 5c). However, for the first time in 
Fig. $3 \delta^{13} \mathrm{C}$ of soil respiration, by treatment, for aspen $(\mathbf{a}-\mathbf{c})$ and birch + aspen (d-f) community types. Values are means with $1 \mathrm{SE}(n=3)$. Within a community type, $P$ values signify significant differences among treatment means for the relevant contrasts (control vs elevated $\mathrm{O}_{3}$; elevated $\mathrm{CO}_{2}$ vs elevated $\mathrm{CO}_{2}+\mathrm{O}_{3}$ ). An asterisk denotes sample dates when soil moisture was unusually high or low compared to adjacent sampling intervals (see text and Fig. 6)
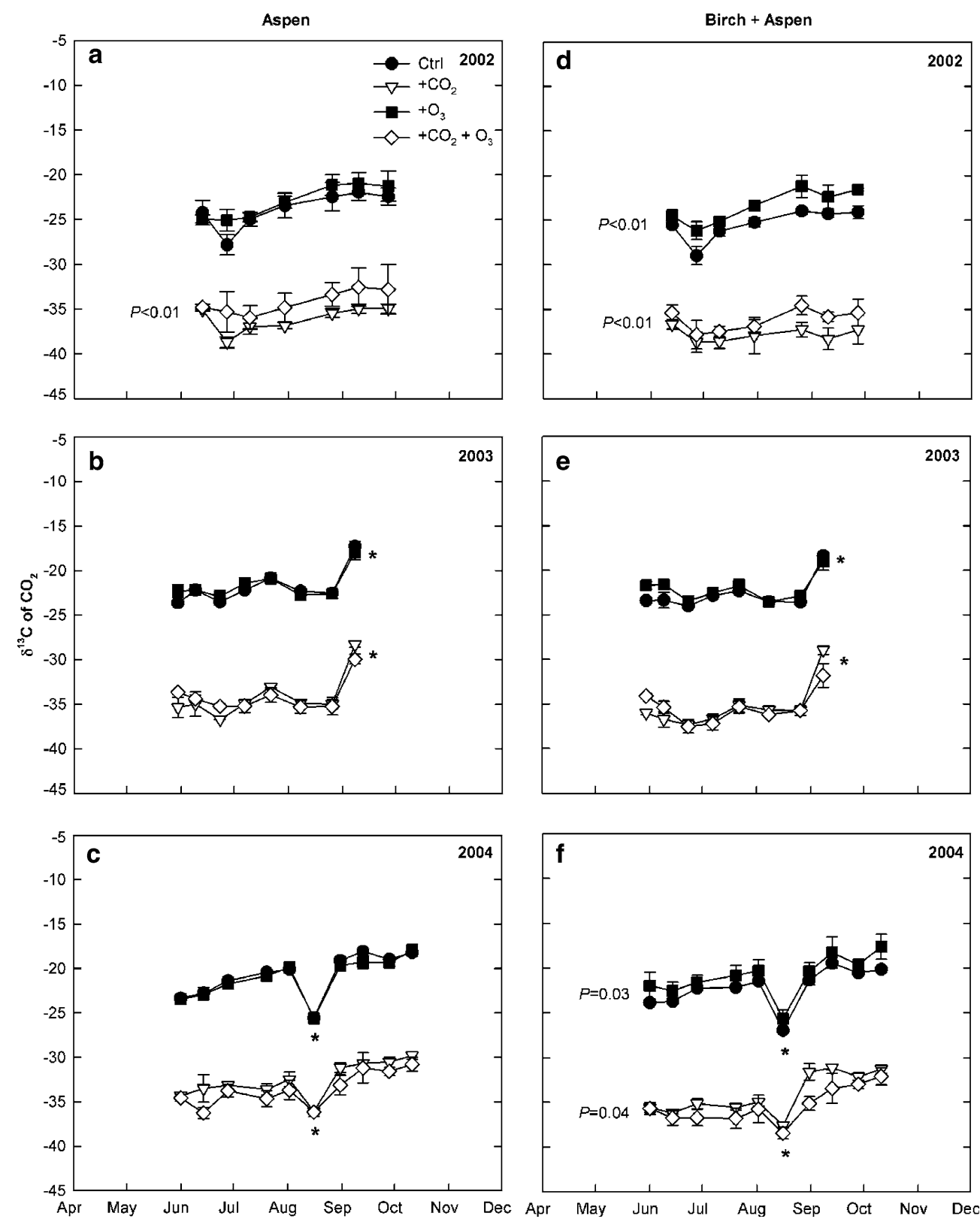

the birch + aspen community type, there was significantly more new $\mathrm{C}$ in soil respiration in the elevated $\mathrm{CO}_{2}+\mathrm{O}_{3}$ treatment (Fig. 5f). Growing season means were roughly $70-75 \%$ in the elevated $\mathrm{CO}_{2}+\mathrm{O}_{3}$ treatment, compared with $60-65 \%$ in the elevated $\mathrm{CO}_{2}$ treatment (Fig. 5f).

During the peak growing season (June-September), there was also considerable variation in the isotopic signature of soil respiration. Prime examples of such variability occurred on 16 August 2004 (Fig. 3c, f), when the $\delta^{13} \mathrm{C}$ of soil respiration was more depleted in ${ }^{13} \mathrm{C}$, and on 8 September 2003, when the isotopic signature was enriched in ${ }^{13} \mathrm{C}$ (Fig. 3b, e). In these examples, significant deviations from average growing season values were apparent across all treatments and community types (Fig. 3). Percentage soil moisture data from the same time periods (Fig. 6) suggest that changes in the atmosphere-plant-soil water potential gradient can result in a significant shift in the $\delta^{13} \mathrm{C}$ of soil respiration.

\section{Discussion}

\section{Soil respiration}

Understanding the future distribution of fixed atmospheric carbon in the terrestrial biosphere is a major goal in many experiments with elevated atmospheric $\mathrm{CO}_{2}$, and these experiments have often demonstrated increased photosynthetic gain and larger plant biomass (Curtis and Wang 1998; Ainsworth and Long 2005). Perhaps the most common response that plants exhibit 

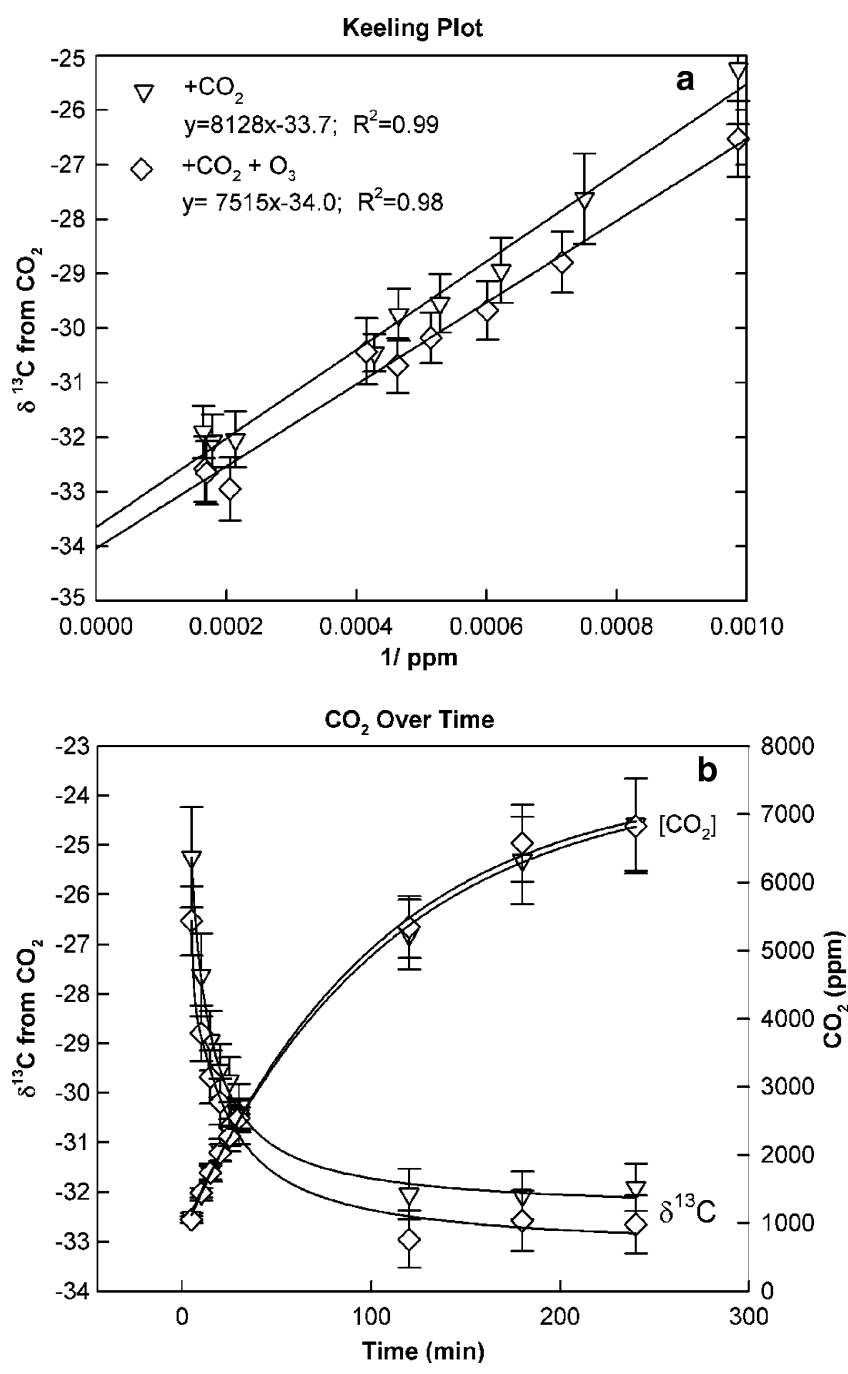

Fig. 4 a Keeling plot of soil respiration for gas samples collected from wide-mouth bottles on 19 September 2004. Values are means with $1 \mathrm{SE}(n=15)$ with a linear regression fitted to each dataset. b $\mathrm{CO}_{2}$ concentration and the $\delta^{13} \mathrm{C}$ values of the $\mathrm{CO}_{2}$ plotted against time. A quadratic line was fitted to each data set in which values are means with $1 \mathrm{SE}(n=15)$

to elevated $\mathrm{CO}_{2}$ is increased fine root production and biomass (Rogers et al. 1994; Pregitzer et al. 1995, 2000a; Tingey et al. 2000; Matamala et al. 2003; Norby et al. 2004). Increases in fine root growth and maintenance respiration at elevated $\mathrm{CO}_{2}$ must certainly be one of the reasons we observed a significant increase in soil respiration in the elevated $\mathrm{CO}_{2}$ treatment, compared to other treatments, during the first 4 years of growth (King et al. 2001, 2004). Increases in root growth at elevated $\mathrm{CO}_{2}$ also result in a greater absolute flux of carbon into the soil, where root detritus is a primary substrate for microbial metabolism (Zak et al. 2000). In general, elevated atmospheric $\mathrm{CO}_{2}$ stimulated soil respiration compared to the control treatment in all years (growing seasons 5-7), across both community types. Although these differences were not always statistically significant in a given year or community type, they usually were.
Like elevated $\mathrm{CO}_{2}$, tropospheric $\mathrm{O}_{3}$ causes direct physiological changes in plants. These changes include decreased activity and concentration of Rubisco, reduced photosynthesis, increased metabolic costs to synthesize antioxidant compounds and repair damaged leaves, and possibly decreased phloem loading (Anderson 2003). Ozone also decreases stomatal conductance and leaf lifespan. The net result of ozone damage to canopies is that net assimilation decreases and compensatory demand for carbohydrates to repair damaged leaves increases, i.e., shoot sink strength increases. This can lead to decreased availability of photosynthate for export to roots, and roots become a relatively weaker sink for plants exposed to elevated $\mathrm{O}_{3}$ (Anderson 2003). Evidence from greenhouse and open-top chamber studies demonstrate that $\mathrm{O}_{3}$ does, in fact, reduce carbon allocation to roots (Manning et al. 1971; Gorissen and van Veen 1988; Rennenberg et al. 1996). Plants exposed to elevated $\mathrm{O}_{3}$ also have lower levels of root non-structural carbohydrates and lower rates of respiration (Grulke et al. 2001; Coleman et al. 1996). However, lower rates of root respiration may be due to lower root biomass, not lower rates of respiration per unit root mass (Anderson 2003). In our experiment, the elevated $\mathrm{O}_{3}$ treatment almost always exhibited the lowest mean rates of soil respiration, which is what we hypothesized based on our understanding of how $\mathrm{O}_{3}$ might influence root physiology and the flux of carbon from root systems into the soil. Rates of soil respiration in the elevated $\mathrm{O}_{3}$ treatment were $2 \%$ lower than controls in 2002 and averaged $16 \%$ lower in 2003-2004, but these differences were usually not statistically significant.

Soil respiration in response to the elevated $\mathrm{CO}_{2}+\mathrm{O}_{3}$ treatment is perhaps the most interesting result we observed. During the 2003-2004 growing seasons there was more absolute soil respiration in the interaction treatment than in the elevated $\mathrm{CO}_{2}$ treatment, even though tree growth, root biomass and net primary productivity in the experiment have followed the hypothesized pattern through the first 7 years of the experiment: elevated $\mathrm{CO}_{2}(+25 \%$ aspen; $+45 \%$ birch + aspen $)>$ elevated $\mathrm{CO}_{2}+\mathrm{O}_{3}(-7.8 \%$ aspen; $+8.4 \%$ birch + aspen $) \approx$ control $>$ elevated $\mathrm{O}_{3}(-23 \%$ aspen; $-13 \%$ birch + aspen) (percentage change in NPP relative to control treatment; King et al. 2005). What has caused this time transient switch in soil $\mathrm{CO}_{2}$ efflux among treatments?

The treatments could alter canopy leaf area, which might then drive a change in soil temperature. In our experiment, elevated tropospheric $\mathrm{O}_{3}$ has reduced canopy leaf area and elevated $\mathrm{CO}_{2}$ has increased leaf area compared to the control treatment (Karnosky et al. 2005). There was a significant elevated $\mathrm{O}_{3}$ effect on soil temperature in the birch + aspen community type in 2003 and both community types in 2004 (Fig. 1). Therefore, one explanation for the switch to more soil respiration in the elevated $\mathrm{CO}_{2}+\mathrm{O}_{3}$ treatment compared to the elevated $\mathrm{CO}_{2}$ treatment may be related to changes in LAI. Changes in LAI could alter the amount of radiation reaching the 
Fig. 5 Estimates of the percentage of new $\mathrm{CO}_{2}-\mathrm{C}$ $\left(+\mathrm{CO}_{2}\right)$ in soil respiration measured during the 2002-2004 growing seasons in the $(\mathbf{a}-\mathbf{c})$ aspen and $(\mathbf{d}-\mathbf{f})$ birch + aspen community types. Values are means with $1 \mathrm{SE}(n=3)$. New $\mathrm{CO}_{2}-\mathrm{C}\left(+\mathrm{CO}_{2}\right)$ represents $\mathrm{C}$ fixed by photosynthesis since fumigation began in 1998 . Within each year and community type, $P$ values indicate significant differences among the elevated $\mathrm{CO}_{2}$ and $\mathrm{CO}_{2}+\mathrm{O}_{3}$ treatments
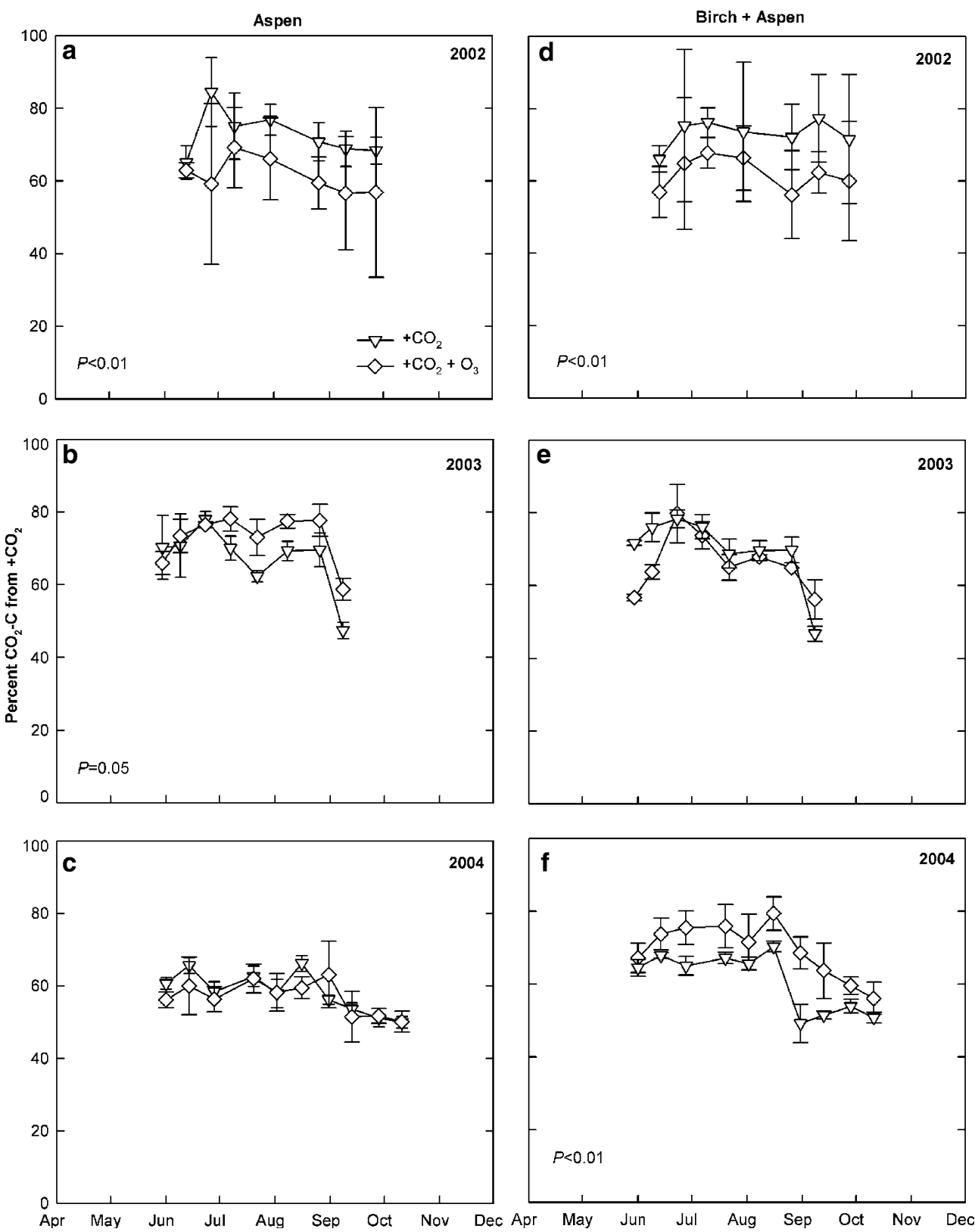

soil surface and this may have only become apparent in 2003-2004 because it took several years for the canopies to reach maximum LAI.

Another possible explanation for the transient response in soil respiration might be treatment effects on the input of substrates for microbial metabolism. In a recent factorial $\mathrm{CO}_{2} \times \mathrm{O}_{3}$ open-top chamber experiment with silver birch, Kasurinen et al. (2004) also reported the greatest rates of soil respiration in the elevated $\mathrm{CO}_{2}+\mathrm{O}_{3}$ treatment. It is possible that $\mathrm{O}_{3}$ damages the canopy, but the capacity to repair the canopy and restore $\mathrm{C}$ translocation to fine roots is inherently greater because of more efficient photosynthesis at elevated $\mathrm{CO}_{2}$ (Ainsworth and Long 2005). This leads to the interesting hypothesis that fine root biomass might be as large or larger in the $\mathrm{CO}_{2}+\mathrm{O}_{3}$ treatment when compared to the control treatment, but mean root lifespan could be shorter, causing an increase in the turnover rate of root biomass. The net result would be greater $\mathrm{C}$ flux from roots to the soil, and more substrate for microbial metabolism in the interaction treatment. The independent measurements of the $\delta^{13} \mathrm{C}$ of soil respiration discussed below support the notion of a substrate-induced, time-transient response in $\mathrm{CO}_{2}$ efflux in the interaction treatment.

\section{$\delta^{13} \mathrm{C}$ of soil respiration}

The $\delta^{13} \mathrm{C}$ of soil respiration and subsequent mixing model calculations provide interesting insight into the factors driving variability in rates of soil respiration. 
Fig. 6 Percentage soil moisture for the aspen $(\mathbf{a}-\mathbf{c})$ and birch + aspen $(\mathbf{d}-\mathbf{f})$ community types over the course of the 2002-2004 growing seasons. Measurements of soil moisture occurred the same day as measurements of soil temperature, soil respiration, and $\delta^{13} \mathrm{CO}_{2}$. An asterisk denotes sample dates when the $\delta^{13} \mathrm{C}$ of soil respiration changed abruptly over the course of the growing season (see text and Fig. 3)
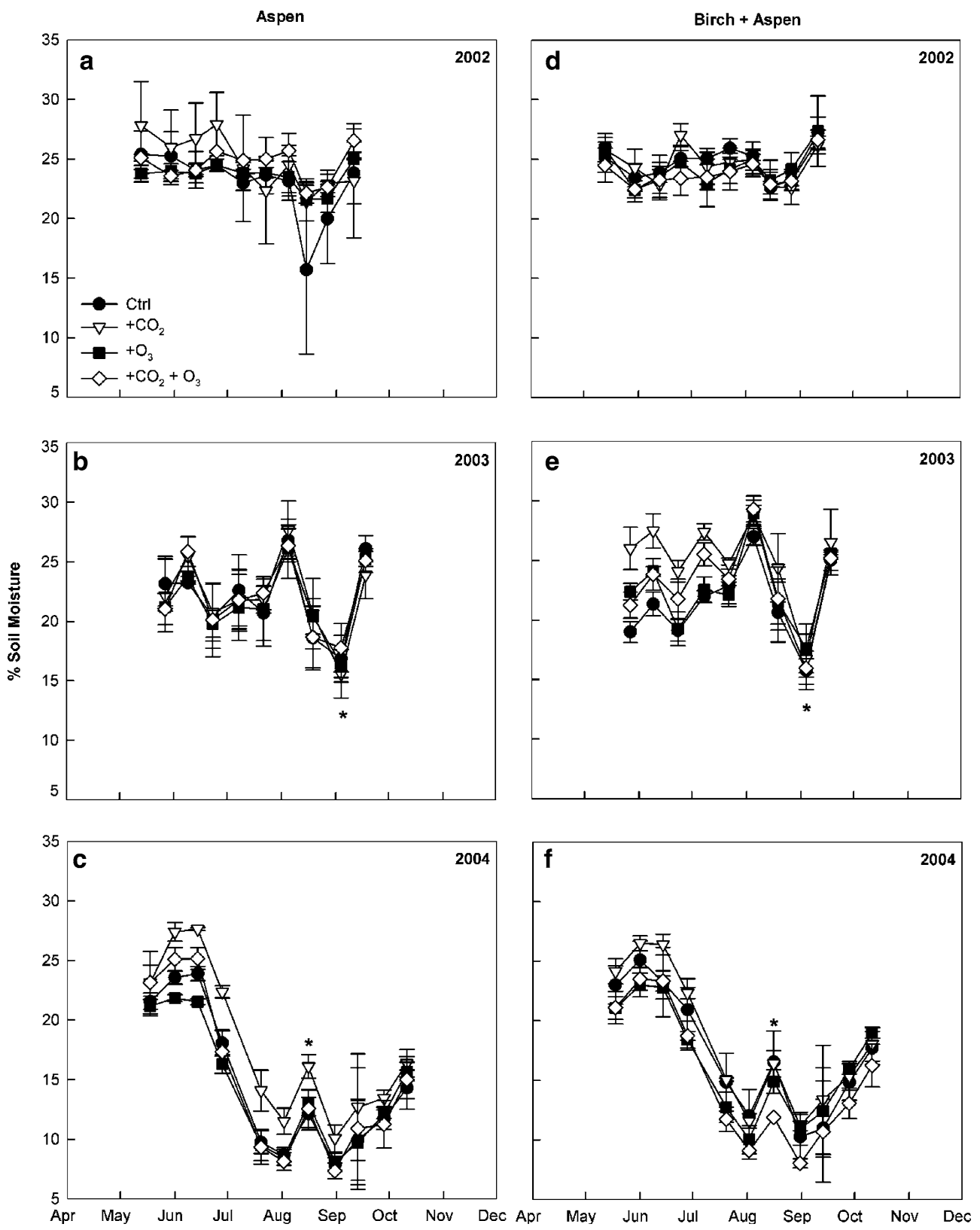

Mixing model calculations generally agree with independent rates of respiration measured with the infrared gas analyzer (IRGA). For example, the IRGA measurements and mixing model calculations illustrate the switch to more new $\mathrm{C}$ respiring in the $\mathrm{CO}_{2}+\mathrm{O}_{3}$ treatment during the 2003 and 2004 growing seasons. In our study, we estimated that new $\mathrm{C}$ allocated to the belowground plant-soil system since the inception of the experiment accounted for an estimated $60-80 \%$ of the efflux of $\mathrm{C}$ from the soil during the peak of the growing season (June-September; Fig. 5). These results are similar to estimates of root-mycorrhizal respiration reported by Högberg et al. $(2001,2002)$ for boreal forests.

The variability in $\delta^{13} \mathrm{C}$ within and among years is also very interesting. It seems the $\delta^{13} \mathrm{C}$ of soil respiration may be sensitive to changes in soil moisture (see examples in
Figs. 3, 6). Ekblad and Högberg (2001) demonstrated the isotopic signature of soil respiration is sensitive to changes in the atmosphere-plant-soil water potential gradient on times steps of 1-4 days, and they suggest that high $\delta^{13} \mathrm{C}$ values were caused by effects of air humidity on isotope fractionation during photosynthesis. McDowell et al. (2004) and Knohl et al. (2005) also demonstrate significant short-term changes in the $\delta^{13} \mathrm{C}$ of ecosystem respiration, and both studies suggest changes in the isotopic signature of ecosystem respiration are related to changes in atmospheric vapor pressure deficit. Earlier, we demonstrated that rates of root respiration decline when soils are dry (Burton et al. 1998). It is possible in this FACE experiment that the relative contributions of new $\mathrm{C}$ from root respiration and old $\mathrm{C}$ from microbial respiration change with soil 
moisture status. Regardless of the underlying mechanism(s), the isotopic signature of soil respiration changed $4-6 \%$ during the growing season between 10 - to 14-day sampling intervals and significant changes appear to be driven by changes in the atmosphere-plant-soil water potential continuum.

\section{Uncertainty in isotope analysis and interpretation}

Correspondence between the $\delta^{13} \mathrm{C}$ measurements on 19 September 2004, $4 \mathrm{~h}$ after closing the lids on the Nalgene bottles and the Keeling plots were very close if we correct for the estimated $8 \%$ of atmospheric $\mathrm{CO}_{2}$ trapped in the chambers when the lids were closed. However, the rate of $\mathrm{CO}_{2}$ diffusion into the closed chamber will vary with the rate of soil respiration, which is greatly influenced by soil temperature. The rate at which ${ }^{13} \mathrm{CO}_{2}$ diffuses into the chambers is also related to the $\delta^{13} \mathrm{C}$ of soil $\mathrm{CO}_{2}$ (Cerling et al. 1991), and we show the $\delta^{13} \mathrm{C}$ of soil $\mathrm{CO}_{2}$ varies with treatment and apparently sometimes with percentage soil moisture. Even though we found very close correspondence between the Keeling plots and the 4-h averages on 19 September 2004, we caution against over-interpretation of our mixing model calculations.

Phillips and Gregg (2001) present a useful approach to understanding the reliability of results generated by standard isotope mixing models, results like those presented in Fig. 5. Using the methods of Philips and Gregg (2001), the $95 \%$ confidence intervals for the percentage of new $\mathrm{C}$ respired in 2002 were approximately $\pm 25 \%$. In 2003-2004 the 95\% confidence intervals became more reliable $(\sim \pm 14 \%)$ after we increased the number of $\delta^{13} \mathrm{C}$ sample chambers from 1 to 5 in each community type. There are many potential sources of variation that can contribute to changes in the isotopic signature of soil respiration and we have already discussed some of them. Great care should be exercised in constructing and interpreting estimates of ecosystem mass balance or partitioning the gross efflux of soil $\mathrm{CO}_{2}$ into component parts based on changes in the $\delta^{13} \mathrm{C}$ of soil $\mathrm{CO}_{2}$. We present the estimates of new $\mathrm{C}$ in soil respiration in Fig. 5 with a clear understanding that these estimates are somewhat uncertain.

Nevertheless, three points regarding the relationship between soil respiration measurements and the treatment responses seem quite clear. First, new $\mathrm{C}$ dominates soil respiration and its relative contribution to total soil respiration is apparently tightly coupled to tree physiology. Reports of the tight coupling of tree physiology and soil respiration are increasing and the use of stable isotopes has helped us better understand the mechanisms driving changes in soil respiration (Andrews et al. 1999; Högberg et al. 2001, 2002; Steinmann et al. 2004; McDowell et al. 2004; Knohl et al. 2005). Second, there was a relatively good correspondence in how these experimental ecosystems responded to treatments over 3 years when we compared measured rates of soil respiration to relative changes in the $\delta^{13} \mathrm{C}$ of soil respiration. This is encouraging because the two sets of measurements are independent estimates of how soil respiration responded to treatments. Finally, changes in the $\delta^{13} \mathrm{C}$ of soil respiration seem to be a very sensitive indicator of the physiological status of ecosystems.

\section{Test of original hypotheses}

Our initial hypotheses were that soil respiration would exhibit a rank order among the treatments as follows: elevated $\mathrm{CO}_{2}>$ control $\approx$ elevated $\mathrm{CO}_{2}+\mathrm{O}_{3}>$ elevated $\mathrm{O}_{3}$, and these predictions were based on our predictions of how the experimental treatments would alter NPP. We also hypothesized that proportionally more new $\mathrm{C}$ would be respired from the elevated $\mathrm{CO}_{2}$ treatment compared to the interaction treatment, because NPP and C flux from the root system would be greater at elevated $\mathrm{CO}_{2}$. These predictions fell apart during the 2003-2004 growing seasons when both rates of soil respiration and the proportion of new $\mathrm{C}$ respired were usually greatest in the elevated $\mathrm{CO}_{2}+\mathrm{O}_{3}$ treatment. A recent $\mathrm{CO}_{2} \times \mathrm{O}_{3}$ factorial open-top chamber experiment in Finland also reported that rates of soil respiration were greatest in the elevated $\mathrm{CO}_{2}+\mathrm{O}_{3}$ treatment, and the authors speculate the combination of the two trace gases somehow stimulates soil respiration (Kasurinen et al. 2004). There are several different ways that $C$ cycling in the soil could be stimulated by the combination of the two trace gases. One possibility is that $\mathrm{O}_{3}$, alone or in combination with $\mathrm{CO}_{2}$, reduces average root lifespan and increases the input of root detritus to the soil, stimulating microbial respiration of labile substrates in the rhizosphere. Another possibility is that some genotypes and species are more susceptible to $\mathrm{O}_{3}$ in these experimental ecosystems than others. We know that $\mathrm{O}_{3}$ is inducing individual tree mortality (Karnosky et al. 2005). In the interaction treatment, the less susceptible survivors may exhibit rapid compensatory growth because photosynthesis is inherently more efficient at elevated $\mathrm{CO}_{2}$ (Ainsworth and Long 2005). Compensatory growth of survivors along with the input of $\mathrm{C}$ from tree mortality results in a transient increase in total belowground $\mathrm{C}$ inputs. Leaf area regulation of radiation reaching the soil surface and subsequent changes in soil temperature may also be an important driver of the observed treatment differences in soil respiration. Elevated $\mathrm{O}_{3}$ did significantly increase soil temperature in 2003 and 2004 (Fig. 1). We could outline other speculative scenarios, but regardless of the mechanism(s) driving the increase in soil respiration in the elevated $\mathrm{CO}_{2}+\mathrm{O}_{3}$ treatment, the $\delta^{13} \mathrm{C}$ measurements seem to indicate an increase in $\mathrm{C}$ allocation to the belowground plant-soil system during the 2003-2004 growing seasons. Thus, the independent soil respiration and $\delta^{13} \mathrm{C}$ measurements both indicate a time-transient ecosystem response toward greater soil $\mathrm{CO}_{2}$ efflux in the 
interaction treatment only during years 6-7 of the experiment as the canopy closed and reached maximum LAI. These results are important because they demonstrate that soil respiration does not necessarily follow from our stylized predictions of how atmospheric $\mathrm{CO}_{2}$ and $\mathrm{O}_{3}$ influence net assimilation and NPP. Will soil $\mathrm{CO}_{2}$ efflux continue to be absolutely higher in the interaction treatment as we move into the future? Alternatively, are the results we report here simply timetransient and will these ecosystems move back towards our original predictions, which were supported by measurements of soil respiration for the first 5 years of the experiment (King et al. 2001, 2004)? What are the mechanisms driving this ecosystem-level change in $\mathrm{C}$ efflux from the soil? Will soil carbon cycling in young and old forests exhibit similar responses to changes in the Earth's atmosphere? Very little is known about how elevated $\mathrm{CO}_{2}$ and $\mathrm{O}_{3}$ interact to influence belowground processes, but many of the Earth's forests will be exposed to increasing concentrations of both traces gases in the next decades. The interaction treatment did not follow our original predictions and we do not understand why.

Acknowledgements Noah Karberg, Jennifer Eikenberry, Angela Piket, Andy Burton and Robin Johnson, along with 12 undergraduate students, contributed to the field measurements. Tom Boutton and Diane Pataki assisted in the interpretation of ${ }^{13} \mathrm{C}$ data. This research was supported by the US Department of Energy-Office of Biological and Environmental Research through its Program for Ecosystem Research, the USDA Forest Service (Northern Global Change and North Central Research Station), National Science Foundation (DEB, DBI/MRI), and Michigan Technological University. G. Hendry, K. Lewin, and J. Nagey from Brookhaven National Laboratory and D. Karnosky and J. Sober of Michigan Technological University have been instrumental to the successful establishment and implementation of this complicated field experiment.

\section{References}

Ainsworth EA, Long SP (2005) What have we learned from 15 years of free-air $\mathrm{CO}_{2}$ enrichment (FACE)? A meta-analytic review of the responses of photosynthesis, canopy properties and plant production to rising $\mathrm{CO}_{2}$. New Phytol 163:351-372

Albritton DL, Meira Filho LG, Cubasch U, Da X, Ding Y, Griggs DJ, Hewitson B, Houghton JT, Isaksen I, Karl T, McFarland M, Meleshko VP, Mitchell JFB, Noguer M, Nyenzi BS, Oppenheimer M, Penner JE, Pollonais S, Stocker T, Trenberth KE (2001) Technical summary. In: Houghton JT, Ding Y, Griggs DJ, Noguer M, van der Linden PJ, Xiasou D (eds) Climate change 2001: the scientific basis. Cambridge University Press, Cambridge, pp 21-83

Anderson CP (2003) Source-sink balance and carbon allocation belowground in plants exposed to ozone. New Phytol 157:213-228

Andrews JA, Harrison KG, Matamala R, Schlesinger WH (1999) Separation of root respiration from total soil respiration using carbon-13 labelling during free-air carbon dioxide enrichment (FACE). Soil Sci Soc Am J 63:1429-1435

Burton AJ, Pregitzer KS, Zogg GP, Zak DR (1998) Drought reduces root respiration in sugar maple forests. Ecol Appl $8: 771-778$

Cerling TE, Solomom DK, Quade J, Bowman JR (1991) On the isotopic composition of carbon in soil carbon dioxide. Geochim Cosmochim Acta 55:3403-3405
Coleman MD, Dickson RE, Isebrands JG, Karnosky DF (1996) Root growth and physiology of potted and field-grown trembling aspen exposed to ozone. Tree Physiol 16:145-152

Curtis PS, Wang X (1998) A meta-analysis of elevated $\mathrm{CO}_{2}$ effects on woody plant mass, form, and physiology. Oecologia 113:299-313

Davidson GR (1995) The stable isotopic composition and measurement of carbon in soil $\mathrm{CO}_{2}$. Geochim Cosmochim Acta 59:2485-2489

Dickson RE, Lewin KF, Isebrands JG, Coleman MD, Heilman WE, Riemenschneider DE, Sober J, Host GE, Hendrey GR, Pregitzer KS, Karnosky DF (2000) Forest atmosphere carbon transfer storage-II (FACTS II)-The aspen free-air $\mathrm{CO}_{2}$ and $\mathrm{O}_{3}$ enrichment (FACE) project in an overview. USDA Forest Service North Central Experiment Station. General Tech Rep NC-214, pp 68

Ehleringer JR, Buchmann N, Flanagan LB (2000) Carbon isotope ratios in belowground carbon cycle processes. Ecol Appl $10: 412-422$

Ekblad A, Högberg P (2001) Natural abundance of ${ }^{13} \mathrm{C}$ in $\mathrm{CO} 2$ respired from forest soils reveals speed of link between tree photosynthesis and root respiration. Oecologia 127:305-308

Felzer B, Kicklighter D, Melillo J, Wang C, Zhuang Q, Prinn R (2004) Effects of ozone on net primary production and carbon sequestration in the conterminous United States using a biogeochemistry model. Tellus 54B:230-248

Fowler D, Flechard C, Skiba U, Coyle M, Cape JN (1998) The atmospheric budget of oxidized nitrogen and its role in ozone formation and deposition. New Phytol 139:11-23

Fowler D, Cape JN, Coyle M, Smith RI, Hjellbrekke AG, Simpson D, Derwent RG, Johnson CE (1999) Modeling photochemical oxidant formation, transport, deposition, and exposure of terrestrial ecosystems. Environ Pollut 100:43-55

Gorissen A, van Veen JA (1988) Temporary disturbance of translocation of assimilates in Douglas-firs caused by low levels of ozone and sulfur dioxide. Plant Physiol 88:559-563

Grulke NW, Anderson CP, Hogsett WE (2001) Seasonal changes in above- and belowground carbohydrate concentration of ponderosa pine along a pollution gradient. Tree Physiol 21:173181

Högberg P, Nordgren A, Buchmann N, Taylor AFS, Ekblad A, Högberg MN, Nyberg G, Ottosson-Löfvenius M, Read DJ (2001) Large-scale forest girdling shows that currect photosynthesis drives soil respiration. Nature 411:789-792

Högberg P, Nordgren A, Agren GI (2002) Carbon allocation between tree root growth and root respiration in boreal pine forest. Oecologia 132:579-581

Janssens IA, Kowalski AS, Longdoz B, Ceulemans R (2000) Assessing forest soil $\mathrm{CO}_{2}$ efflux: an in situ comparison of four techniques. Tree Physiol 20:23-32

Karnosky DF, Zak DR, Pregitzer KS, Awmack CS, Bockheim JG, Dickson RE, Hendrey GR, Host GE, King JS, Kopper BJ, Kruger EL, Kubiske ME, Lindroth RL, Mattson WJ, McDonald EP, Noormets A, Oksanen E, Parsons WFJ, Percy KE, Podila GK, Riemenschneider DE, Sharma P, Sober A, Sober J, Jones WS, Anttonen S, Vapaavuori E, Isebrands JG (2003) Tropospheric $\mathrm{O}_{3}$ moderates responses of temperate hardwood forests to elevated $\mathrm{CO}_{2}$ : A synthesis of molecular to ecosystem results from the Aspen FACE project. Funct Ecol 17:287-307

Karnosky DF, Pregitzer KS, Zak DR, Kubiske ME, Hendry GR, Weinstein D, Nosal M, Percy KE (2005) Scaling ozone responses of forest trees to the ecosystem level in a changing climate. Plant Cell Environ 28:965-981

Kasurinen A, Kokko-Gonzales P, Riikonen J, Vapaavuori E, Holopainen T (2004) Soil $\mathrm{CO}_{2}$ efflux of two silver birch clones exposed to elevated $\mathrm{CO}_{2}$ and $\mathrm{O}_{3}$ levels during three growing seasons. Global Change Biol 10:1654-1665

King JS, Pregitzer KS, Zak DR, Karnosky DF, Isebrands JG, Dickson RE, Hendrey GR, Sober J (2001) Fine root biomass and fluxes of soil carbon in young stands of paper birch and trembling aspen as affected by elevated atmospheric $\mathrm{CO}_{2}$ and tropospheric $\mathrm{O}_{3}$. Oecologia 128:237-250 
King JS, Hanson PJ, Bernhardt E, DeAngelis P, Norby RJ, Pregitzer KS (2004) A multi-year synthesis of soil respiration responses to elevated atmospheric $\mathrm{CO}_{2}$ from four forest FACE experiments. Global Change Biol 10:1027-1042

King JS, Kubiske ME, Pregitzer KS, Hendrey GR, Giardina CP, McDonald EP, Quinn VA, Karnosky DF (2005) Tropospheric $\mathrm{O}_{3}$ compromises net primary production in young stands of trembling aspen, paper birch, and sugar maple in response to elevated atmospheric $\mathrm{CO}_{2}$. New Phytol (in press)

Knohl A, Werner RA, Brand WA, Buchmann N (2005) Short-term variations in the $\delta^{13} \mathrm{C}$ of ecosystem respiration reveals link between assimilation and respiration in a deciduous forest. Oecologia 142:70-82

Krupa S, McGrath MT, Andersen CP, Booker FL, Burkey KO, Chappelka AH, Chevone BI, Pell EJ, Zilinskas BA (2000) Ambient ozone and plant health. Plant Dis 85:4-12

Loya WM, Pregitzer KS, Karberg NJ, King JS, Giardina CP (2003) Reduction of soil carbon formation by tropospheric ozone under increased carbon dioxide levels. Nature 425:705707

Manning WJ, Feder WA, Papia PM, Perkins I (1971) Influence of foliar ozone injury on root development and root surface fungi of pinto bean plants. Environ Pollut 1:305-312

Matamala R, Gonzàlez-Meler MA, Jastrow JD, Norby RJ, Schlesinger WH (2003) Impacts of fine root turnover on forest NPP and soil C sequestration potential. Science 21:1385-1387

McDowell NG, Bowling DR, Bond BJ, Irvine J, Law BE, Anthoni P, Ehleringer JR (2004) Response of carbon isotopic content of ecosystem, leaf, and soil respiration to meteorological and physiological driving factors in a Pinus ponderosa ecosystem. Global Biogeochem Cycles 18:GB1013

Norby RJ, Ledford J, Reilly CD, Miller NE, O'Neill EG (2004) Fine-root production dominates response of a deciduous forest to atmospheric $\mathrm{CO}_{2}$ enrichment. Proc Natl Acad Sci USA 101:9689-9693

Pataki DE, Ehleringer JR, Flanagan LB, Yakir D, Bowling DR, Still CJ, Buchmann N, Kaplan JO, Berry JA (2003) The application and interpretation of Keeling plots in terrestrial carbon cycle research. Global Biogeochem Cycles 17:22-1-22-14
Percy KE, Awmack CS, Lindroth RL, Kubiske ME, Kopper BJ, Isebrands JG, Pregitzer KS, Hendrey GR, Dickson RE, Zak DR, Oksanen E, Sober J, Harrington R, Karnosky DF (2002) Altered performance of forest pests under $\mathrm{CO}_{2}$ - and $\mathrm{O}_{3}$-enriched atmospheres. Nature 420:403-407

Phillips DL, Gregg JW (2001) Uncertainities in source partitioning using stable isotopes. Oecologia 127:171-170

Pregitzer KS, Zak DR, Curtis PS, Kubiske ME, Teeri JA, Vogel CS (1995) Atmospheric $\mathrm{CO}_{2}$, soil nitrogen and fine root turnover. New Phytol 129:579-585

Pregitzer KS, Zak DR, Maziasz J, DeForest J, Curtis PS, Lussenhop J (2000a) Interactive effects of atmospheric $\mathrm{CO}_{2}$ and Soil-N availability on fine roots of Populus tremuloides. Ecol Appl 10:18-33

Pregitzer KS, King JS, Burton AJ (2000b) Responses of fine roots to temperature with emphasis on trees. New Phytol 147:105115

Rennenberg H, Herschbach C, Poole A (1996) Consequences of air pollution on shoot-root interactions. J Plant Physiol 148:296301

Rogers HH, Runion GB, Krupa SV (1994) Plant responses to atmospheric $\mathrm{CO}_{2}$ enrichment with emphasis on roots and the rhizosphere. Environ Pollut 83:155-189

Steinmann K, Siegwolf RTW, Saurer M, Körner C (2004) Carbon fluxes to the soil in a mature temperate forest assessed by ${ }^{13} \mathrm{C}$ isotope tracing. Oecologia 141:489-501

Tingey DT, Phillips DL, Johnson MG (2000) Elevated $\mathrm{CO}_{2}$ and conifer roots: effects on growth, life span and turnover. New Phytol 147:87-103

$\mathrm{Xu}$ C, Lin G, Griffin K, Sambrotto RN (2004) Leaf respiratory $\mathrm{CO}_{2}$ is ${ }^{13} \mathrm{C}$-enriched relative to leaf organic components in five species of $\mathrm{C}_{3}$ plants. New Phytol 163:499-505

Zak DR, Pregitzer KS, King JS, Holmes WE (2000) Elevated atmospheric $\mathrm{CO}_{2}$, fine roots and the response of soil microorganisms: a review and hypothesis. New Phytol 147:201-222 